\title{
KEPRIBADIAN TOKOH UTAMA NOVEL 9 SUMMERS 10 AUTUMNS KARYA IWAN SETYAWAN
}

\author{
Hajar Arohmah, Nugraheni Eko Wardhani, Edy Suryanto \\ Universitas Sebelas Maret \\ Surel: hajararohmah@student.uns.ac.id
}

\begin{abstract}
The research aims to describe (1) structure of novel 9 Summers 10 Autumns by Iwan Setyawan; (2) characteristic of main character personality on novel 9 Summers 10 Autumns by Iwan Setyawan; (3) the value of character education on novel 9 Summers 10 Autumns by Iwan Setyawan; and (4) the relevance of novel 9 Summers 10 Autumns by Iwan Setyawan as literature learning materials in SMA. This research is a qualitative studying using descriptive qualitative and document analysis. The data sources are document and informant. The technique sampling of this research using purposive sampling. Data validity test uses irangulation theory. Data analysis text use interactive method. The result shows (1) structure of novel 9 Summers 10 Autumns by Iwan Setyawan have a correlation; (2) Iwan as main character fill of mature personality criterias by Gordon Allport; (3) novel 9 Summers 10 Autumns have fiveteen types representation the value of character education; and (4) novel 9 Summers 10 Autumns fill criteria as a good literature learnings material.
\end{abstract}

Keywords: the main character personality, the value of character education, literature learnings material

Abstrak: Penelitian ini bertujuan untuk mendeskripsikan: (1) struktur pembangun novel 9 Summers 10 Autumns karya Iwan Setyawan; (2) sifat-sifat kepribadian tokoh utama yang muncul dalam novel 9 Summers 10 Autumns karya Iwan Setyawan; (3) nilai pendidikan karakter yang terkandung dalam novel 9 Summers 10 Autumns karya Iwan Setyawan; dan (4) relevansi novel 9 Summers 10 Autumns karya Iwan Setyawan sebagai materi pembelajaran sastra di SMA. Penelitian ini merupakan penelitian kualitatif dengan menggunakan metode deskriptif kualitatif dan analisis dokumen. Sumber data penelitian ini adalah dokumen dan informan. Teknik pengambilan subjek penelitian yang digunakan dalam penelitian ini adalah purposive sampling. Validitas data dilakukan menggunakan triangulasi teori. Teknik analisis data menggunakan model interaktif. Hasil penelitian ini menunjukkan (1) struktur pembangun novel 9 Summers 10 Autumns saling berkaitan; (2) Iwan sebagai tokoh utama memenuhi tujuh kriteria kepribadian yang sehat menurut Gordon Allport; (3) novel 9 Summers 10 Autumns terdiri atas lima belas jenis representasi pendidikan karakter; dan (4) novel 9 Summers 10 Autumns memenuhi kriteria sebagai materi pembelajaran sastra yang baik.

Kata kunci: kepribadian tokoh utama, nilai pendidikan karakter, materi pembelajaran sastra

\section{PENDAHULUAN}

Pembelajaran sastra (Indonesia) di Sekolah Menengah Atas (SMA) merupakan bagian dari pembelajaran bahasa Indonesia. Keberadaan pembelajaran sastra yang tidak berdiri sendiri berpengaruh pada materi atau bahan ajar sastra menjadi lebih 
sempit. Syafrial (2014: 72) dalam penelitiannya menyebutkan bahwa kedudukan materi sastra pada kurikulum-kurikulum sebelumnya tetap saja „menumpange pada mata pelajaran bahasa Indonesia. Apalagi pada Kurikulum 2013, dengan dijadikannya bahasa Indonesia sebagai penghela mata pelajaran lain tentu akan keberadaan materi sastra dalam pelajaran bahasa Indonesia semakin kehilangan tempat. Berdasarkan hal tersebut, perlu adanya penggunaan dan pemilihan materi atau bahan ajar sastra dari luar buku wajib yang disediakan.

Salah satu jenis karya sastra yang dapat dijadikan sebagai materi ajar adalah novel. Novel merupakan salah satu bentuk karya sastra yang menggambarkan realitas kehidupan manusia secara luas. Terdapat dua unsur pembentuk novel, yaitu unsur intrinsik dan ektrinsik. Unsur intrinsik merupakan unsur pembentuk novel yang di dalamnya terdapat tema, amanat, karakteristik tokoh, alur, latar cerita, sudut pandang cerita (point of view), dan pesan moral (Nurgiyantoro, 2013: 4). Melalui unsur karakteristik tokoh atau penokohan, penulis mencoba menggambarkan amanat atau pesan moral yang ingin disampaikan. Menurut Saraswati (2014: 491), novel yang dihasilkan oleh para pengarang selalu menampilkan tokoh yang memiliki karakter tertentu sehingga dapat dikatakan bahwa novel juga menggambarkan kejiwaan manusia, walaupun pengarang hanya menampilkan tokoh itu secara fiksi.

Berbagai macam judul novel yang terbit, tidak begitu saja dapat digunakan sebagai materi pembelajaran sastra. Kelayakan novel sebagai materi pembelajaran perlu diuji dan dipertimbangkan. Baik tidaknya sebuah novel dapat dilihat dari struktur novel dan nilai pendidikan karakter yang terkandung di dalamnya. Pendidikan karakter biasanya tercermin dari tokoh dalam menghadapi konflik atau permasalahan yang menimpa.

Pendekatan psikologi sastra dapat digunakan untuk mengkaji penggambaran sifat atau karakter tokoh dalam sebuah novel. Pendekatan ini merupakan salah satu interdisiplin ilmu antara psikologi dan sastra yang dapat digunakan dalam telaah sastra. Fokus pendekatan psikologi sastra adalah analisis watak atau karakteristik tokoh. Menurut Minderop (2010: 59), daya tarik psikologi sastra ialah pada masalah manusia yang melukiskan potret jiwa. 
Pendidikan karakter dapat ditanamkan sejak kecil melalui berbagai hal. Salah satu cara yang paling efektif adalah dengan penanaman karakter dalam pembelajaran di sekolah. Dalam pengajaran sastra, nilai karakter dapat ditumbuhkan melalui karya sastra. Memanfaatkan karya sastra, seni, dan budaya dalam rangka menopang pendidikan karakter berarti menghargai, melestarikan warisan nenek moyang sekaligus membatasi pengaruh budaya asing, sebab segala sesuatu yang terkandung di dalamnya adalah khazanah kultural (Ratna, 2014: 234). Pada penelitian Azizah (2016: 152) disebutkan bahwa pembelajaran nilainilai pada novel akan menyentuh aspek afektif peserta didik, sehingga dapat membina karakter peserta didik agar menjadi manusia yang berbudi luhur.

Salah satu novel yang memiliki tokoh utama yang berkepribadian menarik dan nilai pendidikan karakter adalah novel 9 Summers 10 Autumns karya Iwan Setyawan. Novel tersebut menceritakan perjuangan seorang anak yang gigih dalam meraih cita-citanya. Nilai-nilai pendidikan karakter yang terkandung dalam novel tersebut dapat direlevansikan dalam pembelajaran sastra di Sekolah Menengah Atas (SMA). Pada Kurikulum 2013 jenjang SMA, pembelajaran sastra diajarkan pada mata pelajaran bahasa Indonesia pada kelas XI semester II dengan Kompetensi Dasar (KD) meliputi: (1) Menganalisis kebahasaan resensi setidaknya dua karya yang berbeda; dan (2) Mengkonstruksi sebuah resensi dari buku kumpulan cerita pendek atau novel yang sudah dibaca. Oleh karena itu, fokus penelitian ini mencoba untuk mengkaji psikologi tokoh utama, nilai pendidikan karakter, dan relevansi sebagai materi pembelajaran di SMA.

\section{METODE PENELITIAN}

Penelitian ini dilakukan selama empat bulan dari bulan Desember 2017 sampai Maret 2018 dengan menggunakan pendekatan deskriptif kualitatif. Penelitian deskriptif kualitatif yaitu data yang dikumpulkan adalah kata-kata, kalimat, atau gambar yang memiliki arti lebih dari pada sekadar angka-angka (Sutopo, 2006: 35). Penelitian ini dilakukan dengan cara menyimak secara cermat kepribadian tokoh utama dan nilai pendidikan karakter dalam novel 9 Summers 10 
Autumns. Setelah itu, peneliti mencari informasi mengenai relevansi novel tersebut dengan materi pembelajaran sastra di SMA.

Sumber data penelitian ini adalah dokumen dan informan. Teknik pengambilan subjek penelitian yang digunakan dalam penelitian ini adalah purposive sampling. Validitas data dilakukan menggunakan triangulasi teori. Teknik analisis data menggunakan model interaktif yang meliputi empat komponen, yaitu pengumpulan data, reduksi data, penyajian data, dan penarikan kesimpulan.

\section{HASIL PENELITIAN DAN PEMBAHASAN}

\section{Struktur Novel 9 Summers 10 Autumns}

Karya sastra dibangun oleh dua unsur, yaitu unsur intrinsik dan unsur ektrinsik. Unsur intrinsik merupakan unsur yang membangun karya sastra dari dalam untuk membantu pembaca dalam memahami isi cerita. Unsur yang pertama adalah tema. Tema merupakan gagasan abstrak utama yang terdapat dalam sebuah karya sastra atau yang secara berulang-ulang dimunculkan baik secara eksplisit maupun (yang banyak ditemukan) implisit lewat pengulangan motif (Baldic dalam Nurgiyantoro, 2013:115). Tema dalam novel 9 Summers 10 Autumns adalah perjuangan dan kekeluargaan, seperti kutipan berikut.

Perjuangan keluargaku bagaikan sesuatu yang tak mungkin dilakukan. Seorang sopir truk dengan dua anak kuliah, di Bogor dan di Malang, dua anak lagi masih di SMA dan SMP! Gelombang semakin besar, tapi pelayaran kami tak berhenti. Kami terus maju, kami terus memberanikan iri, karena berdiam hanya akan menunggu badai...(Setyawan, 2013: 100).

Iwan sebagai tokoh utama menceritakan berbagai kesulitan yang dialami keluarganya. Berbagai kesulitan itu Iwan dan keluarganya lalui dengan perjuangan yang tidak mudah. Selain perjuangan, pengarang juga memunculkan banyak cerita tentang keluarga Iwan yang sederhana. Tanpa kasih sayang dari orang tua dan dukungan dari empat saudarnya, Iwan tidak akan menjadi pribadi yang matang dan berhasil meraih impiannya. Hal tersebut terlihat pada kutipan berikut.

Masa kecilku mungkin tak seindah dan selepas mereka, tapi kehangatan di bawah rumah kecilku telah menyelamatkanku. Jalan hidupku mungkin akan 
berbeda, I would have been so lost, tanpa kesederhanaan Ibu, tanpa perjuangan keras Bapak, tanpa cinta yang hangat dari saudara-saudaraku. Memori masa kecil membuat aku bijak dalam mengenal diriku sekarang (Setyawan, 2013: 209).

Iwan adalah tokoh utama dalam novel 9 Summers 10 Autumns. Penggambaran tokoh Iwan dalam novel ini detail sehingga membuktikan bahwa tokoh tersebut adalah tokoh utama. Penulis juga memunculkan tokoh Iwan lebih dominan dan diceritakan terus menerus dalam novel. Hal ini sesuai dengan pendapat Nurgiyantoro (2013: 258) tokoh utama adalah tokoh yang diutamakan penceritaannya dalam novel yang bersangkutan. Iwan juga merupakan tokoh protagonis, sebab Iwan digambarkan sebagai sosok yang memiliki sifat baik. Hal tersebut sejalan dengan Altenberns dan Lewis (Nurgiyantoro, 2013: 261) bahwa tokoh protagonis merupakan tokoh yang kita kagumi yang salah satu jenisnya secara popular. Tokoh Iwan secara fisiologis digambarkan sesorang yang memiliki tubuh pendek dan kecil. Ia memiliki karakter rajin, pandai, pekerja keras, mandiri, dan mudah bergaul.

Tokoh tambahan dalam novel 9 Summers 10 Autumns Bapak Abdul Hasim, Ibu Ngatinah, Mbak Isa, Mbak Inan, Rini, Mira, bocah kecil berbaju merah putih, Audrey, Nicolas Auclair, Mas Yani, Mas Mul, Firdaus Ria Herlambang, Lek Tukeri dan Lek Sum, Pak Andi Hakim Nasution, Mbak Ati, Mbak Yanti, dan Kalista. Keberadaan tokoh tambahan menjadi pelengkap konflik yang terjadi pada tokoh utama. Dalam hal ini, konflik yang terjadi pada tokoh tambahan tidak begitu mendominasi cerita. Hal tersebut sesuai dengan pendapat Nurgiyantoro (2013: 258) bahwa pemunculan tokoh tambahan biasanya diabaikan, atau kurang mendapat perhatian.

Latar dalam novel 9 Summers 10 Autumns meliputi: latar tempat, latar waktu, dan latar sosial-budaya. Latar tempat dalam novel ini terdiri dari beberapa lokasi yang sebagian besar terjadi di New York, Kota Bogor, Kota Batu, dan Kota Jakarta. Latar waktu yang digunakan dalam novel 9 Summers 10 Autumns meliputi: 4 Juli 2001, 4 Oktober 1997, 4 Juli 2009, 29 September 2000, 1 Oktober 2000, September 2006, Januari 2009, Sore Hari, Sabtu Sore, Pagi Hari, Tengah Malam, dan Rabu Malam. Latar sosial-budaya yang terdapat dalam novel ini 
adalah penggambaran kehidupan di New York yang begitu ramai, memiliki kriminalitas yang tinggi, dan banyaknya pusat perbelanjaan yang mewah dan berkelas.

Alur yang digunakan dalam novel 9 Summers 10 Autumns adalah alur campuran. Pengarang memadukan alur maju dan alur sorot balik untuk menjelaskan peristiwa yang terjadi pada masa lalu melalui peristiwa yang terjadi saat ini. Salah satu contoh penceritaan yang menggunakan alur maju adalah saat Iwan akan bertemu dengan bocah kecil berseragam merah putih. Penceritaan yang menggunakan alur sorot balik yakni ketika pengarang menceritakan kembali kebahagiaan saat wisudanya.

Sudut pandang yang digunakan dalam novel 9 Summers 10 Autumns adalah sudut pandang persona pertama "aku" tokoh utama (first-person point of view). Novel ini merupakan kisah nyata yang dialami oleh Iwan, oleh karenanya Iwan sebagai pengarang sekaligus tokoh menggunakan kata sapaan "aku" sebagai gaya bercerita. Selain itu, pengarang menjadikan tokoh Iwan sebagai tokoh utama yang mengetahui keseluruhan cerita dari awal hingga akhir. Hal tersebut sesuai dengan Nurgiyantoro (2013: 348) bahwa dalam sudut pandang "Aku" tokoh utama, si "aku" mengisahkan berbagai peristiwa dan tingkah laku yang dialaminya, baik yang bersifat batiniah, dalam diri sendiri, maupun fisik, hubungannya dengan sesuatu yang di luar dirinya.

Amanat yang ingin disampaikan pengarang melalui novel 9 Summers 10 Autumns ini yaitu jangan takut untuk memiliki cita-cita dan berani mewujudkannya. Pengarang mencoba untuk menceritakan susah payah mewujudkan impiannya, meskipun yang apa yang dimiliki tidak sempurna. Selain itu, pengarang juga menunjukkan bahwa perjuangan dan kerja keras akan membuahkan hasil. Hal ini terlihat dengan keberhasilan Iwan menjadi salah satu manajer data processing yang berkerja di New York. Pesan moral lainnya adalah kasih sayang orang tua dan dukungan keluarga menjadi bekal penting untuk mewujudkan cita-cita. Hal tersebut dapat dilihat pada kutipan berikut.

...Meskipun marmer itu sudah retak-retak, impian ini masih menyala dan kami tetap menyimpannya. Nilai-nilai inilah yang membuat aku yakin bahwa 
impian haruslah menyala dengan apapun yang kita miliki, meskipun yang kita miliki tidak sempurna, meskipun itu retak-retak (Setyawan, 2013: 21).

\section{Kepribadian Tokoh Utama Novel 9 Summers 10 Autumns}

Kepribadian adalah kesan yang diberikan seseorang kepada orang lain yang diperoleh dari sesuatu yang dipikirkan, dirasakan, diperbuat yang terungkap melalui perilaku seseorang (Jaenudin, 2012: 101). Setiap orang memiliki kepribadian yang beragam. Perbedaan kepribadian ini dipengaruhi oleh kematangan masing-masing individu. Orang yang berkepribadian sehat, akan dapat menjalani kehidupan dengan lebih optimis. Sebaliknya, orang yang berpandangan neurotis menjalani hidupnya dengan penuh perasaan negatif. Kepribadian yang dimiliki oleh tokoh utama dalam novel 9 Summers 10 Autumns dapat diketahui melalui tujuh kriteria kepribadian sehat menurut Gordon Allport berikut.

\section{Perluasan Perasaan Diri}

Sifat perluasaan perasaan diri pada tokoh Iwan terlihat ketika semasa kecil Iwan belajar dengan tekun melebihi teman-temannya. Bagi Iwan kecil, belajar merupakan hal yang penting dan menantang. Sifat perluasaan perasaan diri ditandai dengan adanya anggapan penting terhadap suatu kegiatan. Iwan menganggap penting rutinitas belajar yang dilakukannya dini hari. Hal ini relevan dengan pendapat Allport (Schultz, 1991: 30) yang menyatakan bahwa apabila mengerjakan suatu pekerjaan karena percaya bahwa pekerjaan itu penting (dengan alasan karena pekerjaan itu menantang kemampuan, atau karena mengerjakan pekerjaan itu dengan sebaik-baiknya membuat kita merasa puas), maka hal itu menandakan seorang partisipan yang autentik dalam pekerjaan itu. Adapun sifat tersebut terlihat pada kutipan berikut.

Aku belajar dengan tekun, mungkin lebih daripada teman-temanku. Aku lebih sering bangun pagi sekali dan belajar lebih lama. Tak jarang aku bangun sekitar jam satu pagi, di bawah lampu redup dan di tengah ketakutan akan hantu-hantu yang sering diceritakan orang-orang tua di sekitarku. Aku melawan rasa kantuk dan rasa takut untuk belajar, untuk melawan rasa takut akan kegagalan. Aku memulai perjuangan untuk membebaskan rasa kecilku ini (Setyawan: 2013: 69).

\section{Memiliki Hubungan Diri yang Hangat dengan Orang-Orang Lain}


Sikap bersahabat dan mudah mengenal orang baru terlihat pada tokoh Iwan ketika datangnya seorang siswa pertukaran pelajar dari Kanada bernama Nico. Ia mudah berinteraksi dan beradaptasi dengan hal yang tidak banyak orang lainnya bisa lakukan. Apa yang dilakukan Iwan kepada Nico menunjukkan salah satu ciri hubungan diri yang hangat dengan orang lain yaitu keintiman (cinta) terhadap teman akrab. Hal tersebut tercermin pada penelitian Yoanita (2011: 785) yang menyampaikan bahwa orang yang mempunyai hubungan hangat dengan orang lain akan mempunyai rasa kekeluargaan dan cinta yang hangat terhadap siapa saja. Hal ini dapat dilihat pada kutipan berikut.

Aku selalu berusaha mendekati Nico untuk mengetahui dia lebih jauh. Aku ingin mengupas budaya, gaya hidup dan mempraktikan bahasa Inggrisku. Nico sosok yang hangat dan mudah didekati. Dan, karena tak banyak remanteman yang berani berbincang dengan Nico, aku bisa akrab dengan dia... (Setyawan, 2013: 91).

\section{Terjaminnya Keamanan Emosional}

Menurut Allport (Baihaqi, 2008: 99) keamanan emosional seseorang yang memiliki kepribadian sehat ditandai oleh tiga kualitas yaitu, penerimaan diri, menerima emosi-emosi manusia, sabar terhadap kekecewaan. Salah satu bagian yang menunjukkan kualitas penerimaan diri Iwan adalah pribadi yang mudah menyalahkan. Semasa kecil, Iwan dengan mudah menerima kondisi rumah yang tidak luas itu untuk hidup bersama orang tua dan empat saudara perempuannya. Meskipun kondisi keluarga yang sangat sederhana, Iwan tidak pernah meminta agar dibuatkan kamar. Hal tersebut sesuai dengan kutipan berikut.

Ketika memasuki SMP, aku lebih sering tidur di ruang tamu, di depan TV, di atas karpet cokelat. Musuh terbesar yang aku takuti adalah gelapnya malam dan tikus-tikus yang biasa berkeliaran dari dapur. Sebelum tidur, aku selalu memeriksa pintu dapur supaya selalu tertutup rapat dan menyumpal bagian bawah pintu dengan kain pel atau keset supaya tikus-tikus tidak mengunjungi tempatku tidur (Setyawan, 2013: 8-9).

\section{Memiliki Persepsi Realistis}

Kesadaran Iwan akan kemampuan orang tuanya merupakan pandangan objektif yang dimiliki oleh Iwan. Sebab, orang-orang yang memiliki kepribadian sehat memandang dunia mereka secara objektif. Jika mereka mencapai keberhasilan, itu sebuah kewajaran atau hasil kerja yang ditekuninya. Jika mereka 
mengalami kegagalan, itu sebuah pengalaman biasa-biasa saja yang tidak harus disesali dengan bermuram-muram (Allport dalam Baihaqi, 2008: 101). Keluarga yang tidak berada secara kecukupan finansial dalam novel 9 Summers 10 Autumns merupakan salah satu bentuk kegagalan perekonomian yang dialami oleh Iwan. Akan tetapi, Iwan menyikapi hal tersebut dengan penerimaan, bukan dengan rasa penyesalan yang berlebihan. Hal tersebut dapat dilihat pada kutipan berikut.

Di tengah teman-temanku ini, aku melihat rumah lantai keramik, halaman yang luas, sepeda motor, mobil, video player, telepon, piano, atau tumpukan buku cerita. Mataku terbuka. Aku begitu mengerti kemampuan orangtuaku dan aku tak bisa menunggu keajaiban untuk mengubah ini. Aku harus bekerja, sekarang. Dengan reputasiku sebagai siswa berprestasi, aku menerima tawaran untuk memberikan les privat, seperti yang dilakukan kakakku...(Setyawan, 2013: 84).

\section{Memiliki Keterampilan-keterampilan dan Tugas-tugas}

Setelah kelulusan dari IPB, Iwan bekerja di sebuah perusaahan pengolahan data. Di perusahaan tersebut, Iwan bekerja dengan lebih keras dan berusaha untuk tepat waktu dalam pekerjaannya. Hal tersebut Iwan lakukan untuk memberikan yang terbaik kepada perusahaan. Apa yang dilakukan Iwan pada bagian tersebut menunjukan bahwa Iwan adalah seseorang yang bertanggung jawab dengan tugastugas yang diberikan. Hal ini sesuai dengan pendapat Allport (Schultz, 1991: 33) bahwa tidaklah cukup hanya memiliki keterampilan-keterampilan yang relevan, kita harus menggunakan keterampilan-keterampilan itu secara ikhlas, antusias, melibatkan dan menempatkan diri sepenuhnya dalam pekerjaan kita. Sifat tersebut terdapat pada kutipan berikut.

Aku mulai memasuki dunia profesional dan mempelajari seluk beluk data processing. Dengan fokus dan kerja keras, aku mulai menikmati pekerjaan pertamaku ini. Tak jarang, aku berada di kantor lebih lama daripada temanteman yang lain untuk belajar, mengejar ketinggalan atau mempersiapkan pekerjaan supaya bisa diselesaikan sebelum jadwal. Semua kau lakukan karena aku tak ingin menjadi biasa saja, aku ingin memberikan yang terbaik, dan "berbeda" dari orang lain...(Setyawan, 2013: 167).

\section{Memiliki Pemahaman Diri}

Seseorang yang memiliki pemahaman diri yang baik adalah seseorang yang mengenali gambaran diri sesuai keadaan nyata yang dimiliki. Iwan paham betul 
dengan tubuhnya yang kecil dan pendek adalah sebuah keterbatasan yang dimilikinya. Semasa SMP, Iwan bahkan selalu menjadi yang terkecil di kelasnya. Keadaan ini menjadikan sebuah pemahaman diri pada Iwan untuk belajar lebih serius meraih masa depannya dengan lebih mengandalkan kemampuan otak daripada fisik. Hal tersebut sesuai dengan kutipan berikut.

...Memasuki dunia baru ini pula aku menyadari bahwa aku tidak bisa mengandalkan kegiatan fisik karena tubuhku yang lebih kecil dan pendek dibandingkan teman-teman seusiaku. Aku hampir selalu menjadi yang terkecil di kelas. Ada sedikit harapan di benakku, setelah dikhitan di kelas 2 SMP, hormon-hormon akan berubah dan aku akan bertambah tinggi. Ternyata hanya suaraku yang berubah dan aku masih menjadi yang terkecil di kelas. Dengan keterbatasan itu pula, aku meyakinkan diri bahwa harus "bermain" serius dengan buku-bukuku, dengan otakku...(Setyawan, 2013: 68).

\section{Filsafat Hidup yang Mempersatukan}

Menurut Allport (Baihaqi, 2008:103) seseorang mustahil memiliki suatu kepribadian yang sehat jika dia tidak didukung adanya aspirasi-aspirasi dan arah ke masa depan. Representasi tokoh Iwan terkait aspirasi ke masa depan ditunjukkan pada bagian keberaniannya untuk bermimpi dan memiliki cita-cita. Bagi Iwan, sesulit apapun keadaan yang menimpanya, ia tetap memiliki mimpi untuk diwujudkan. Hal ini sesuai dengan kutipan berikut.

...Meskipun marmer itu sudah retak-retak, impian ini masih menyala dan kami tetap menyimpannya. Nilai-nilai inilah yang membuat aku yakin bahwa impian haruslah menyala dengan apapun yang kita miliki, meskipun yang kita miliki tidak sempurna, meskipun itu retak-retak (Setyawan, 2013: 21).

\section{Nilai Pendidikan Karakter dalam Novel 9 Summers 10 Autumns}

Novel sebagai salah satu karya sastra merupakan sarana yang cukup efektif untuk menanamkan nilai pendidikan karakter pada siswa. Nilai-nilai tersebut terbentuk melalui berbagai karakter pada tokoh yang tergambar pada alur cerita. Dengan begitu, pembaca dapat memahami nilai pendidikan karakter apa saja yang terkandung dalam novel dan selanjutnya dapat meneladani karakter tersebut.

Kementerian Pendidikan Nasional dalam (Syarbini, 2014:37) merumuskan delapan belas nilai karakter yang dikembangkan menjadi nilai pendidikan karakter. Nilai-nilai karakter tersebut meliputi: religius, jujur, toleransi, disiplin, 
kerja keras, kreatif, mandiri, demokratis, rasa ingin tahu, semangat kebangsan, cinta tanah air, menghargai prestasi, cinta damai, bersahabat dan komunikatif, gemar membaca, peduli lingkungan, peduli sosial, dan bertanggungjawab. Dalam novel 9 Summers 10 Autumns ini ditemukan lima belas nilai pendidikan karakter yang meliputi:

\section{Religius}

Religius merupakan sikap dan perilaku yang patuh dalam melaksanakan ajaran agama yang dianutnya, toleran terhadap pelaksanaan ibadah agama lain, dan hidup rukun dengan pemeluk agama lain. Nilai religius dalam novel 9 Summers 10 Autumns terlihat ketika Iwan mulai rajin untuk salat lima waktu dan salat Tahajud semasa ia berkuliah di Bogor. Bagi Iwan, doa-doa dalam salat memberikannya kekuatan baru dan menyembuhkan kerinduan pada keluarganya.

\section{Jujur}

Jujur adalah perilaku yang didasarkan pada upaya menjadikan dirinya sebagai orang yang selalu dapat dipercaya dalam perkataan, tindakan, dan pekerjaan. Kejujuran Iwan terlihat ketika ia mengungkapkan kembali masa lalunya yang tidak mudah. Ada masa-masa sulit yang ketika dikenang kembali akan membuatnya ingin menangis. Iwan mencoba untuk jujur ketika mengungkap kembali kenangannya di masa lalu.

\section{Toleransi}

Toleransi adalah sikap dan tindakan yang menghargai perbedaan agama, suku etnis, pendapat, sikap, dan tindakan orang lain yang berbeda dari dirinya. Sikap toleransi terlihat ketika Iwan memiliki teman baru dari Kanada yang mengikuti program pertukaran pelajar di SMA-nya. Teman bulenya yang bernama Nico adalah seseorang yang menerima perbedaan budaya dan gaya hidup di Kota Batu.

\section{Disiplin}

Disiplin adalah tindakan yang menunjukkan perilaku tertib dan patuh pada berbagai ketentuan dan peraturan. Karakter disiplin pada novel terlihat ketika Mbak Inan setiap pagi dengan rutin membersihkan rumah. Tidak ada peraturan 
khusus untuk membersihkan rumah, akan tetapi Mbak Inan menjadikan aktivitas itu sebagai kebiasaan yang tidak bisa ditinggalkan setiap harinya.

\section{Kerja Keras}

Kerja keras adalah perilaku yang menunjukkan upaya sungguh-sungguh dalam mengatasi berbagai hambatan belajar dan tugas, serta menyelesaikan tugas dengan sebaik-baiknya. Nilai kerja keras dalam novel terlihat ketika semasa kecil Iwan sangat giat belajar, bahkan ia selalu bangun dini hari untuk belajar. Ia melawan rasa kantuk dan takutnya, karena ia lebih takut akan kegagalan di masa depannya.

\section{Kreatif}

Kreatif adalah berpikir dan melakukan sesuatu untuk menghasilkan cara atau hasil baru dari sesuatu yang dimiliki. Karakter kreatif terlihat pada tokoh Mbak Inan yang menciptakan sebuah warung darurat ketika bulan Ramadhan. Di usianya yang masih belia, Mbak Inan mampu berpikir bagaimana cara mendapatkan uang tambahan.

\section{Mandiri}

Mandiri adalah sikap dan perilaku yang tidak mudah tergantung pada orang lain dalam menyelesaikan tugas-tugas. Nilai karakter mandiri terlihat ketika semasa kecil, Mbak Inan sudah bisa mencari uang sendiri dengan berdagang kuekue kecil dan membantu berjualan di kios tetangganya.

\section{Demokratis}

Demokratis yaitu cara berpikir, bersikap, dan bertindak yang menilai sama hak dan kewajiban dirinya dan orang lain. Sikap demokratis terlihat pada tokoh Ibu yang adil dalam membagi makanan agar semua anggota keluarga mendapat bagian.

\section{Rasa Ingin Tahu}

Rasa ingin tahu adalah sikap dan tindakan yang selalu berupaya untuk mengetahui lebih mendalam dan meluas dari sesuatu yang dipelajarinya, dilihat dan didengar. Karakter tersebut terlihat ketika Iwan sering bertanya tentang seluk- 
beluk berkulaih di jurusan Statistika kepada Mas Mul, teman sekamarnya yang merupakan kakak tingkatnya di jurusan yang sama.

\section{Cinta Tanah Air}

Cinta tanah air yaitu cara berpikir, bersikap, dan berbuat yang menunjukkan kesetiaan, kepedulian, dan penghargaan yang tinggi terhadap bahasa, lingkungan fisik, sosial, budaya, ekonomi, politik, dan bangsa. Sikap cinta tanah air telihat ketika Iwan memutuskan untuk kembali ke tanah kelahirannya setelah beberapa tahun tinggal di New York. Meskipun posisinya semakin matang, Iwan selalu teringat dengan kampung halamannya.

\section{Menghargai Prestasi}

Menghargai prestasi adalah sikap dan tindakan yang mendorong dirinya untuk menghasilkan sesuatu yang berguna bagi masyarakat, dan mengakui serta menghormati keberhasilan orang lain. Nilai ini terlihat ketika Iwan dan keluarganya sangat bangga dengan prestasi Mbak Inan yang menjadi juara pada lomba debat $\mathrm{P} 4$ dan berhasil mengikuti program pertukaran kebudayaan di Jepang.

\section{Bersahabat dan Komunikatif}

Bersahabat dan komunikatif yaitu tindakan yang memperlihatkan rasa senang berbicara, bergaul, dan bekerja sama dengan orang lain. Karakter ini terlihat ketika Iwan menjadi teman dekat Nico yang berasal dari Kanada. Pada saat itu tak banyak teman yang mendekati Nico, Iwan justru memanfatkan kesempatan itu untuk bertukar pikir dan mengasah kemampuan bahasa Inggris Iwan.

\section{Gemar Membaca}

Gemar membaca adalah kebiasaan menyediakan waktu untuk membaca berbagai bacaan yang memberikan kebajikan bagi dirinya. Nilai gemar membaca terlihat ketika Iwan sangat menyukai membaca. Bagi Iwan, buku adalah teman terdekatnya.

\section{Peduli Lingkungan}


Peduli lingkungan yaitu sikap dan tindakan yang selalu berupaya mencegah kerusakan pada lingkungan alam di sekitarnya, dan mengembangkan upaya-upaya untuk memperbaiki kerusakan alam yang sudah terjadi. Nilai peduli lingkungan terlihat ketika Iwan bersama empat saudaranya berupaya untuk menanam tanaman di dekat rumahnya.

\section{Tanggung Jawab}

Tanggung jawab adalah sikap dan perilaku seseorang untuk melaksanakan tugas dan kewajibannya, yang seharusnya dilakukan, terhadap diri sendiri, masyarakat, lingkungan (alam, sosial, dan budaya) negara dan Tuhan Yang Maha Esa. Nilai tanggung jawab terlihat ketika Iwan selalu berusaha menyelesaiakan pekerjaannya sebelum waktu yang ditentukan.

\section{Relevansi Novel 9 Summers 10 Autumns Sebagai Materi Pembelajaran di SMA}

Prinsip dasar dalam pemilihan bahan pembelajaran adalah bahan pembelajaran yang disajikan kepada siswa harus sesuai dengan kemampuan siswanya pada suatu tahapan pengajaran tertentu (Rahmanto 1988:26). Kesesuaian materi dalam pembelajaran sastra dapat ditinjau melalui tiga aspek yaitu, bahasa, kematangan jiwa (psikologi) siswa, dan latar belakang kebudayaan (Rahmanto, 1988: 27). Tiga aspek tersebut merupakan kriteria yang dapat dijadikan prinsip dasar seorang guru untuk memilih materi pembelajaran yang baik. Selain itu, novel yang digunakan sebagai materi pembelajaran juga harus memenuhi kriteria buku penunjang yang baik (Semi dalam Sarumpaet: 2002: 138). Kriteria tersebut meliputi pencapaian tujuan pengajaran, bermanfaat, menarik, memenuhi unsur keterbacaan, dan utuh.

Bahasa yang digunakan dalam novel 9 Summers 10 Autumns cukup mudah dipahami untuk kelompok pembaca usia SMA, sehingga siswa dapat memahami isi novel. Pada hasil temuan diungkapkan bahwa bahasa dalam novel 9 Summers 10 Autumns mengikuti alur cerita, tidak membosankan, dan mampu memberikan pemahaman tentang cerita dalam novel.

Karya sastra yang terpilih untuk diajarkan hendaknya sesuai dengan tahap psikologis pada umumnya dalam suatu kelas. Aspek psikologi dalam novel 9 
Summers 10 Autumns menarik jika diajarkan dalam pembelajaran sastra di SMA, karena tema pendidikan dan perjuangan mewujudkan impian masih jarang diangkat oleh pengarang lain. Hal tersebut memberi dampak baik pada ketertarikan siswa untuk membaca novel yang inspiratif dan dapat memberikan semangat. Hal ini juga berhubungan dengan kriteria menarik yang disampaikan Semi (2002: 139) yang menyebutkan bahwa bahan ajar harus sesuai dengan minat, perhatian, dan gelora batiniah mereka sehingga dapat memancing timbulnya daya tanggap, daya bayang, daya rasa, dan daya pikir.

Dominasi latar cerita di New York tidak mengubah karakter Iwan sebagai orang Indonesia yang berasal dari Kota Batu. Pada hasil temuan, diungkapkan bahwa dominasi latar tersebut memberikan pengetahuan tentang kehidupan di luar negeri. Selain itu, latar belakang Iwan sebagai seorang pelajar dan konsep pendidikan dalam novel sesuai jika diajarkan dalam lingkungan belajar di SMA.

Tujuan pembelajaran tidak hanya berkaitan dengan prestasi belajar siswa. Hal ini sesuai dengan pendapat Semi (Sarumpaet, 2002: 138) bahwa guru harus menyadari dan memahami konsepsi pengajaran dan tujuan pengajaran sastra agar peserta didik memperoleh banyak manfaat, salah satunya nilai-nilai kemanusiaan. Nilai-nilai kemanusiaan dalam hal ini berarti nilai pendidikan karakter yang terkandung dalam novel. Novel 9 Summers 10 Autumns memiliki lima belas karakter yang tercermin melalui beberapa tokoh. Hasil wawancara juga menunjukkan bahwa siswa terinspirasi untuk membuat karya sastra dengan tema yang serupa.

Manfaat yang dapat diambil setelah membaca novel 9 Summers 10 Autumns menurut beberapa siswa antara lain munculnya motivasi untuk melakukan sebuah tindakan dari pesan atau amanat. Selain itu, siswa juga mendapat ide untuk menulis karya sastra seperti cerpen. Adanya manfaat dalam novel tersebut merepresentasikan kriteria bahan ajar yang bermanfaat. Semi (Sarumpaet, 2002:

138) menyatakan bahwa bahan ajar yang bermanfaat berarti dapat memenuhi kebutuhan pengembangan insting etis dan estetis, pengembangan imajinasi, dan daya kritis. 
Kriteria terakhir yang harus dipenuhi sebuah buku penunjang adalah keutuhan. Bahan ajar atau bahan belajar, khususnya yang berupa bacaan sastra harus berupa karya sastra utuh, bukan karya sastra sinopsis (Semi dalam Sarumpaet, 2002: 139). Novel 9 Summers 10 Autumns bukan sebuah sinopsis, novel tersebut adalah karya utuh yang ditulis oleh Iwan Setyawan.

Dengan demikian, dapat disimpulkan bahwa novel 9 Summers 10 Autumns relevan dan sesuai jika dijadikan sebagai materi pembelajaran sastra di SMA. Hal tersebut dapat dilihat dari terpenuhinya tiga aspek kriteria materi pembelajaran sastra yang baik menurut Rahmanto dan lima kriteria buku penunjang yang baik menurut Semi. Selain itu, nilai pendidikan karakter yang terkandung dalam novel 9 Summers 10 Autumns cukup lengkap dan dapat menginspirasi pembacanya.

\section{SIMPULAN}

Berdasarkan hasil analisis dan pembahasan di atas dapat disimpulkan bahwa struktur novel dalam novel 9 Summers 10 Autumns dianalisis menggunakan unsur intrinsik. Unsur intrinsik yang membangun novel 9 Summers 10 Autumns saling berkaitan. Keterkaitan antarunsur di dalamnya membanggun keselarasan antara tema, alur, tokoh, latar, sudut pandang, dan amanat. Antarunsur dalam novel 9 Summers 10 Autumns memiliki keterkaitan yang dapat dilihat melalui tema sebagai jati diri novel. Penggambaran tokoh yang membawa alur cerita akan merepresentasikan tema pada sebuah novel. Alur cerita terbangun melalui latar yang saling berkesinambungan. Adanya konflik dan watak para tokoh dapat memberikan pesan moral kepada pembaca. Sudut pandang dapat menggambarkan seolah-olah peristiwa dalam novel terjadi secara nyata.

Kepribadian sehat yang dimiliki tokoh Iwan sebagai tokoh utama dalam novel 9 Summers 10 Autumns yaitu, (a) perluasan perasaan diri, (b) memiliki hubungan diri yang hangat dengan orang-orang lain, (c) terjaminnya keamanan emosional, (d) memiliki persepsi realistis, (e) memiliki keterampilan-keterampilan dan tugastugas, (f) memiliki pemahaman diri, dan (g) memiliki filsafat hidup yang mempersatukan. Iwan memiliki ketujuh sifat tersebut yang diketahui melalui alur 
cerita dalam novel. Dengan demikian, dapat dikatakan bahwa Iwan secara analisis psikologi merupakan tokoh yang memiliki kepribadian yang sehat.

Nilai pendidikan karakter dalam novel 9 Summers 10 Autumns terdiri atas lima belas karakter, meliputi (a) religius, (b) jujur, (c) toleransi, (d) disiplin, (e) kerja keras, (f) kreatif, (g) mandiri, (h) demokratis, (i) rasa ingin tahu, (j) cinta tanah air, (k) menghargai prestasi, (l) bersahabat dan komunikatif, (m) gemar membaca, (n) peduli lingkungan, dan (o) tanggung jawab. Kelimabelas karakter tersebut tergambar melalui tokoh utama maupun tokoh tambahan. Karakter dalam novel ini yang tercermin melalui para tokoh dapat dikatakan lengkap dan sesuai digunakan sebagai materi pembelajaran sastra.

Berdasarkan hasil analisis dan wawancara dengan informan dapat diketahui bahwa novel 9 Summers 10 Autumns memenuhi tiga kriteria materi pembelajaran sastra yang baik menurut Rahmanto dan lima kriteria kelayakan buku penunjang menurut Semi. Bahasa yang digunakan pengarang mudah dipahami, isi cerita menarik dan inspiratif, serta mengandung nilai pendidikan karakter yang lengkap. Novel 9 Summers 10 Autumns sesuai atau relevan dijadikan sebagai materi pembelajaran sastra pada mata pelajaran bahasa Indonesia di kelas XI SMA. Kompetensi dasar yang sesuai adalah menganalisis bahasa dalam karya sastra dan membuat resensi dari karya sastra.

\section{DAFTAR PUSTAKA}

Azizah, U. N. (2016). “Analisis Konflik Batin Tokoh Utama dan Nilai Pendidikan Karakter Novel Ayat-Ayat Cinta 2 karya Habiburrahman el Shirazy Kajian Psikologi Sastra serta Relevansinya sebagai Materi Pembelajaran Sastra Siswa SMA/SMK Kelas XII”. Skripsi. tidak dipublikasikan, Universitas Sebelas Maret, Surakarta.

Baihaqi, M. (2008). Psikologi Pertumbuhan: Kepribadian Sehat untuk Mengembangkan Optimisme. Bandung: PT Remaja Rosdakarya.

Jaenudin, U. (2012). Psikologi Kepribadian . Bandung: Pustaka Setia.

Minderop, A. (2010). Psikologi Sastra: Karya Sastra, Metode, Teori, dan Telaah

Kasus. Jakarta: Yayasan Pustaka Obor Indonesia. 
Nurgiyantoro, B. (2013). Penilaian Pembelajaran Bahasa Berbasis Kompetensi. Yogyakarta: BPFE-Yogyakarta. . (2013). Teori Pengkajian Fiksi. Yogyakarta: Gadjah Mada University Press.

Rahmanto, B. (1988). Metode Pengajaran Sastra. Yogyakarta: Kanisius.

Ratna, N. K. (2014). Peranan Karya Sastra, Seni, dan Budaya dalam Pendidikan Karakter. Yogyakarta: Pustaka Pelajar.

Saraswati, I. (2013). "Novel Lalita Karya Ayu Utami (Kajian Psikologi Sastra dan Nilai Pendidikan”. Jurnal Basastra, 490-503.

Semi, M. A., dkk. (2002). Buku Pendukung Pengajaran Sastra. Dalam Sarumpaet, R. K. T (Ed). Sastra Masuk Sekolah. (hlm. 134-144). Magelang: Penerbit Indonesiatera.

Setyawan, I. (2013). 9 Summers 10 Autumns. Jakarta: PT Gramedia.

Schultz, D. (1991). Psikologi Pertumbuhan: Model-model Kepribadian Sehat. Terj.Yustinus. Yogyakarta: Penerbit Kanisius.

Syafrial. (2014). "Problematika Bahan Ajar Bidang Sastra dalam Buku Wajib Pelajaran Bahasa Indonesia Kurikulum 2013 di Sekolah Menengah”. Jurnal Bahasa, 71-79. Diperoleh pada 8 Januari 2018, dari http://portalgaruda.org.

Syarbini, A. (2014). Model Pendidikan Karakter dalam Keluarga. Jakarta: PT Gramedia.

Yoanita, I. (2011). "Kepribadian Tokoh Utama Ketika Cinta Bertasibih Episode 1 Karya Habiburrahman El Shirazy Berdasarkan Teori Gordon Allport". Jurnal Artikulasi, 769-792. Diperoleh pada 22 November 2017, dari http://portalgaruda.org. 